\title{
МАСЛО ЦЕЛЕБНОЕ В «ПРОХЛАДНОМ ВЕРТОГРАДЕ» (1672): ЛИНГВОКУЛЬТУРОЛОГИЧЕСКИЙ АСПЕКТ
}

\section{HEALING OIL \\ IN «COOL VERTOGRAD» (1672): LINGUOCULTUROLOGICAL ASPECT}

O. Antsiferova

Summary: This article describes "Cool Vertograd", a literary text of the 17 th century, included in the collection by V.M. Florinsky "Russian common folk herbal and doctor books: collection of medical manuscripts of the 16th and 17th centuries." Observations of the linguistic facts of the chapters on the therapeutic effect of oils are presented. Models of oil names are identified; an attempt is being made to classify oils according to their use for the treatment of certain diseases. There are cases of fixing the identified oil names in the Dictionary of the Russian Academy of Sciences (1789-1794). The fact of using the same oil for the treatment of several diseases is emphasized, which confirms the wellknown conclusion about the predominance of mainly psychotherapeutic treatment in the 17th - 19th centuries. At the same time, the search for specific remedies for a particular disease, reflected in the written text, testifies to the existence of the concept of classification medicine at the end of the 17th century.

Keywords: literary texts of the 18th century; Cool Vertograd, Florinsky V. $\mathrm{M}$; names of oils, application of oils, 17 th century.

\author{
Анциферова Ольга Николаевна \\ К.филол.н., дочент, Уральский государственный \\ медицинский университет, г. Екатеринбург \\ antsiferovaon@yandex.ru
}

Аннотация: Характеризуется «Прохладный вертоград» - памятник письменности XVII В., вошедший в сборник В.М. Флоринского «Русские простонародные травники и лечебники: собрание медицинских рукописей XVI и XVII столетия». Представлены наблюдения за языковыми фактами глав о лечебном действии масел. Выявляются модели наименований масла; осуществляется попытка классификации масел в соответствии с их использованием для лечения определенных заболеваний. Отмечаются случаи фиксации выявленных наименований масел в Словаре Академии Российской (1789-1794). Подчеркивается факт использования одного и того же масла для лечения нескольких заболеваний, что подтверждает известный вывод о преобладании преимущественно психотерапевтической терапии XVII-XIX ВB. При этом отраженный в памятнике письменности поиск специфических средств лечения того или иного заболевания свидетельствует о существовании концепции классификационной медицины в конце XVII В.

Ключевые слова: памятники письменности; Прохладный вертоград, Флоринский В. М.; наименования масел, применение масел, XVII В.

медицины В.М. Флоринским и включено в состав сборника «Русские простонародные травники и лечебники: собрание медицинских рукописей XVI и XVII столетия» (Казань, 1879).

В предисловии к изданию В.М. Флоринский замечает, что в конце одного из списков этого сочинения есть указание на то, что книга переведена с немецкого аптекарского лечебника Hortus Amoenus в 1672 году подьячим Земского приказа Андреем Микифоровым (Никифоровым). Профессор также обращает внимание на то, что это одно из самых популярных медицинских сочинений своего времени. В.Ф. Груздев называет это сочинение энциклопедией средневековых медицинских знаний [Груздев, с. 344], исследователь В.А. Куликов - великолепным трудом по истории лекарствоведения [Куликов, 2012, с. 56].

Известно, что переводчики и переписчики русифицировали иностранные сочинения: они сохраняли те сведения, которые соотносимы с русскими особенностями природы и быта, дополняли книгу новыми фактами, обновляли устаревшую информацию. В этом смысле «Прохладный вертоград» 1672 г., изданный профессором

Это сочинение подготовлено к печати профессором 
B.М. Флоринским, - типичный обрусевший вариант Hortus Amoenus. Обратим внимание на то, что латинское hortus 'огороженное место, фруктовый сад, виноградник' [Дворецкий, с. 367] при переводе заменено церковнославянским вертоград [Фасмер, I, 301]. В.В. Замкова замечает, что в XVIII в. это слово активно употреблялось в сочинениях высокого слога [Замкова, 1975, с. 122]. Следовательно, можно утверждать, что уже в названии переводной книги проявляет себя славянская национальная стихия. Об этом же свидетельствует активное употребление в тексте славянизмов: аще 'если', глава 'голова', власы 'волосы', очи 'глаза', уд 'член', чрево 'живот' и др.

\section{Презенташия информашии о маслах в «Прох^алном вертограце»}

«Прохладный вертоград» включает в себя 340 глав, в части из которых (гл. 212-266) речь идет о маслах как лекарственных средствах. Языковые факты этих глав явились предметом нашего изучения.

Попутно обратим внимание на выводы К.С. Худина, изучающего памятники письменности XVII в. Исследователь утверждает, что слово масло употреблялось в нескольких значениях:

1. масло растительного происхождения;

2. масло животного происхождения (то же, что жир);

3. мазь (потому что маслом мажут) [Худин, 2021, c. 148].

Раздел «Прохладного вертограда», в котором речь идет о лечебном действии масел, называется «О масльхъ, которыя къ чему угодны бываютъ» (здесь и далее сохраняем орфографию памятника письменности). Главы не подчинены алфавитному принципу расположения. Они начинаются предложной конструкцией: «О масль древяномъ», «О горчичномъ масль», «О масль изъ грецкихъ орьховъ» и т.п.

Объем глав и логика изложения сведений о маслах различны. В некоторых главах речь идет о способах приготовления данного лекарственного средства, например: возьми соку листвія рутовы травы полгривенки, масла древянаго 5 гривенокъ (гривенка - весовая единица, равная 204,75 г), воды рьчной 3 гривенки, и вари дондеже ('пока') сокъ и вода укипитъ, и потомъ процьди и сохрани (о рутовом масле). В других главах с первых слов речь идет о целебном действии масла, например: мокрость тьлесную высушаетъ, паденію власовъ пользуетъ, и немочамъ составнымъ ('суставным') и удомъ ('членам тела') разслабленнымъ помогаетъ (о горчичном масле).

При этом заметно желание автора структурировать излагаемый материал, о чем свидетельствует нумерация внутри главы. Нумеруются зоны воздействия масла, например:

1. ТЬмъ масломъ помажемъ жедудокъ...

2. Аще тьмъ масломъ помажешь спину...

3. Тоже масло, аще въ ноздри пускаемъ... (о петрамоновом масле). Нумерация также подчеркивает логику изложения, например в главе «О масле из кирпича»:

4. Изъ кирпича масло составляется сице ('так')...

5. То масло пособляетъ всьмъ студенымъ и мокростнымъ бользнямъ и кашлямъ, и камень дробитъ, и строганіе внутреннее унимаетъ...

6. Рыболовы, коли тьмъ масломъ помазуютъ, тогда множество рыбъ изымаютъ.

\section{Наименования масел в «Прох^адном вертограде»}

Названия масел представляют собой составные наименования, например: редьковое масло, масло ржаное. Причем в ряде наименований используются прилагательные с усеченными окончаниями: кувшинцово масло.

В составе подобных двухкомпонентных наименований зафиксированы отыменные прилагательные с суффиксами:

- ов/ -ев: анисовое, васильковое, бьленово, бобковое, инпериково (возможно, что 'имбирное' [СлРЯ XI-XVII, вып. 6, с. 245]), кедровое, коложарово, кроповое ('укропное' [СлРЯ XI-XVII, вып. 8, с. 72]), кувшинцово, лильево, мастиковое, мозжевеловое, петрамоново, рамоново ('ромашковое' [СлРЯ XIXVII, вып. 21, с. 269]), редьковое, розмариновое, рутовое, сальюмково (из «сальюмковы травы»), скипидаровое, скорпионово, тополіоново, өіалковое ('фиалковое'), эуфорбіево (Euphorbia - растение из семейства молочайных) ;

- -н: арбузное, гвоздичное, губинное («изъ губинной травы»), дынное, коричное, кропивное ('крапивное'), мушкатное, огуречное, пелынное ('полынное'), терпентинное, яичное;

- -енн: тыквенное;

- -ан/-ян (-янн): древяное и древянное, ржаное.

В числе составных наименований зафиксированы подчинительные словосочетания с предложным управлением: масло изъ золота, изъ касатки, изъ кирпича, изъ купоросу, изъ олова.

В составе многокомпонентных наименований вышеназванная предложная конструкция распространяется согласованным определением: масло изъ грецкихъ орьховъ, изъ льсныхъ орьховъ; масло изъ горькихъ миндальныхъ ядеръ, изъ сладкихъ мигдальныхъ ядеръ; масло изъ сьры горючія, изъ струи бобровой, изъ ивьту мушкатнаго, изъ цвьту своробориннаго. 
Зафиксирован единичный случай беспредложного управления в составном наименовании: масло Эфь (нефти).

Два наименования представляют собой описательные конструкции с подчинительной связью: масло изо птицы изъ ластки, кою касаткою зовуть; масло, что не даетъ власомъ рости, гдь помажешъ.

Единичны случаи однокомпонентных наименований масел: бальсамъ ('бальзам'), неөть ('нефть'). Заметим, что в главе «О бальсамь» нет рецепта его изготовления, а лишь обращается внимание на то, с чем его можно смешивать (съ масломъ древяннымъ, съ виномъ фряжскимъ, съ молокомх коровьимъ и др.). По мнению К. С. Худина, бальсамъ мог являться основой для мазей и пластырей [Худин, 2021, с. 158]. В исследуемом нами источнике бальсамъ рекомендуется использовать в составе капель, мази, пластыря и свечей. В главе «О неөьти» поясняется, что означает данное название (неөть есть масло, имьетъ силу распущающую и стравляющую) и следует перечисление недугов, при которых рекомендуется употреблять это лекарственное средство. Обратим внимание на то, что неөть и масло Эфь представлены в разных главах «Прохладного вертограда» и их лечебное действие различно, сведения о способах приготовления этих лекарственных средств отсутствуют.

В единичных случаях даются русифицированные латинские наименования, например: масло васильковое, а по латынь оліумъ базиликони горіофилати; оліумъ касторіумъ ('касторовое масло').

\section{Сведения лингвокультурологического характера, сопровожАаюшие описание масе^}

Как было замечено выше, в некоторых главах речь идет о способах приготовления масла, поэтому имеются сведения об использующейся в то время лабораторной посуде: сосудъ скляничный; скляница; сосудъ, который жаръ терпитъ; муравленый горшокъ (горшок со стекловидным покрытием, закрепленным обжигом).

Есть сведения о том, в составе каких лекарственных форм используется масло и вместе с какими лекарственными формами: масть ('мазь'); пластырь; порохъ ('порошок'); декокціонъ (от лат. decoctio - отвар); гвозди, кои врачеве именуютъ супозиторумъ (от лат. suppositorium 'свеча'). Есть упоминание о том, какие лекарственные средства необходимо принять перед употреблением масла в лечебных целях, например: напередъ того принять пургацію (от лат. purgatio 'очищение, слабительное средство').
Попытка систематизации названий масел в соответствии с их употреблением в лечебных шелях

Спектр лечебного действия масел широк, при этом масло рекомендуется использовать для наружного и внутреннего употребления.

Представим перечень масел в соответствии с их употреблением в лечебных целях. Далее для краткости в составных наименованиях опускаем слово масло.

При лечении психических заболеваний: мозжевеловое («при падучей бользни» 'эпилепсии'); изъ золота («отъ падучей немочи», «отъ манія и отъ меланколія»); изъ кирпича («пособляетъ тьмъ, кто падучею бользнію страждутъ»).

Применятся при лечении внутренних болезней: анисовое («пространство въ грудьхъ отворитъ и тяжко воздыхающимъ помогаетъ), васильковое («немочь сердечную отгонитъ»), гвоздичное («желудковымъ бользнямъ помогаетъ»), изъ горькихъ мигдальныхъ ядеръ («заключеніе жилъ селезенныхъ отворитъ»), изъ золоma («у кого почки немочны или засорятся мокротою»), изъ кирпича («пособляетъ мокростнымъ бользнямъ и камень дробитъ»), изъ купоросу («сердце укрьпляетъ»), изб льсныхъ орьховъ («бользнь печенную и пузырную исцьляетъ»), изъ сладкихъ мигдальныхъ ядеръ («пристоитъ къ печени и къ легкому, бользнь ихъ выведетъ»), изъ цвьту мушкатнаго («желудковымъ бользнемъ помогаетъ»), изъ ивьту своробориннаго («бользнь пузырную и печенную выведетъ»), кропивное («утробу движетъ и өлегму 'флегму' и густую мокрость изо всего тьла выгонитъ»), кувшинцово («язву въ пузырь и въ почкахъ заживляетъ»), мастиковое («немочь печенную исцьлитъ»), мозжевеловое («пристоитъ тьмъ, кои тягостны нутромъ, кишки укрьпляетъ»), мушкатное («желудокъ укрьпляетъ и внутренности уздравляетъ»), пелынное («надыманіе печенное тушитъ, желтость изъ человька выводитъ, стомахъ ('желудок') болящій укрьпляетъ»), петрамоново («тьмъ масломъ помажемъ желудокъ, тогда его укрьпитъ и зяблые уды оживитъ»), рамоново («биеніе трясавичное уйметъ, язвы въ кишкахъ исцеляетъ»), розмариновое («помогаетъ сердечнымъ и желудочнымъ бользнемъ»), рутовое («студеность изъ почекъ и пузыря выведетъ»), сальюмково («немочь пузырную уздравитъ и камень выгонитъ»), скорпіоновое («лечба къ почкамъ, коли камень въ почкахъ»), Эфь («выгоняетъ мочь 'мочу' и камень»).

При лечении горла, ушей и носа: гвоздичное («гортань вычищаетъ и голосъ тончитъ»), из цвьту своробориннаго («пользу творитъ горлу, кое хрипитъ»), өіалковое («уйметъ хрипленіе горляное»); бьленово («отокъ изъ ушей выводитъ»), изъ горькихъ мигдальныхъ ядеръ («ушную бользнь истребитъ»), конопляное («отъ ушной немочи»), мозжевеловое («того масла по капль пускаемъ въ уши»), 
неөть («пособляетъ у кого въ ушахъ болитъ отъ стужи»), эуфорбіево («бользнь изъ ушей выведетъ»), яичное («немочь ушную уйметъ»); рутовое («помазуемъ ноздри, когда залеганіе»).

При лечении глаз: изъ золота (отъ всякой очной 'глазной' бользни»), изъ кирпича («очи льчитъ и слезнаго теченія недопускаетъ»), из ивьту своробориннаго («аще отокъ въ очехъ»), неөть («пособляетъ у кого бьльмо на очехъ, или слеза идетъ»).

При лечении болезней губ, ротовой полости, зубов: изъ кирпича («зубную бользнь уйметъ»), изъ цвьту своробориннаго («помазуемъ губы, кои отъ вьтра трескаются и ртяныя язвы»), өіалковое 'фиалковое' («губное разсьданіе исцьляетъ»), яичное («тьмъ масломъ десны помажемъ, на которой сторонь зубы болятъ»).

При лечении кожных заболеваний: бобковое («и коросту, и свербежъ, и нечистоту тьлесную выгонитъ»), губинное («надутыя и твердыя болячки мягчитъ, мозоли исцьляетъ»), древяное («прыщи полягутъ»), изъ цвьту своробориннаго («помазуемъ надутыя болячки»), изъ олова («прокаженныя мьста исцьляетъ»), кедровое («коросту съ тьла сгонитъ»), коложарово («исцьляетъ угри на лиць надутые и гноеватые»), конопляное («помазуемъ коросту»), кроповое («твердую надутую болячку мягчитъ»), рамоново («исцьляетъ коросту тьлесную»), редьковое («помазуемъ на лиць угри огненныя и гноеватыя»), ржаное («всякіе угри надутыя на лиць исцьляетъ»), рутовое («приложи къ болячкамъ отвореннымъ»), өіалковое 'фиалковое' («исцьляетъ коросту тьлесную»).

При лечении волос: бобковое («власомъ растеніе творитъ»), горчичное («паденію власовъ пользуетъ»).

При лечении ожогов и для предотвращения ожогов: изъ цвьту своробориннаго («ожегъ огненный и водяной живитъ»);

При лечении травм и повреждений тела: бальсамъ («помажемъ свьжія раны, тогда въ одинъ день заживляетъ»), горчичное («укушеніе скорпіона исцьляетъ»), древяное («помазуемъ перешибленныя жилы 'сухожилия'»), коричное («помазуй жилы скорченныя»), неөть («пособляетъ на укушеніе злыхъ ядовитыхъ, коли рану помажешъ), скипидаровое («льчба къ переломленнымъ костямъ»), терпентинное («подогрьвъ въ рану пускаемъ»), тополіоновое («мажемъ всякую переломленную кость и разшибленыя мьста»).

При лечении суставов и позвоночника: горчичное («немочамъ составным 'суставным' помогаетъ»), изъ золота («выгонитъ мокроту изо всьхъ суставовъ»), изъ касатки («суставамъ помогаетъ»); изъ кирпича («больніе въ хребть уйметъ»), изъ струи бобровой («суставы, больную поясницу и хребетъ помазуемъ»), кропивное («хребтовую немочь выводитъ»), лильево («помогаетъ на запаленіе суставовъ»), мозжевеловое («пристоитъ къ ломоть и къ грыжь хребтовой»), неөть («мазати составы 'суставы', кои болятъ»), скипидаровое («льчба къ суставной грыжь»).

При лечении женских болезней: бальсамъ («вычиститъ мастрику 'матку', и заключенное менстрово 'месячные' отворитъ»), бьленово («немочь мастрикову исцьляетъ»), изъ цвьту мушкатнаго («бользни нутреннія женскія исцьляетъ»), изъ горькихъ мигдальныхъ ядеръ («мастрикову бользнь исцьлитъ»), мастиковое («немочь мастрикову исцьлитъ»).

При лечении бессонницы: арбузное, дынное, огуречное («аще тьми маслами ноздри помазуемъ, тогда сонъ наводитъ»); бьленово («сонъ наводитъ, аще въ ноздри пускаемъ»); кувшинцово («сонъ наводитъ»); тополіоново («помазуемъ виски и запястья, тогда сонъ наводитъ»); тыквенное и өіалковое («сонъ наводитъ»).

Применяются как жаропонижающие средства: изъ сьры горючія («кто огневой боленъ, дать въ питьь»), изъ купоросу («жаръ отводитъ»).

При отравлениях: бальсамъ («выгонитъ окормъ 'отравление' изъ нутри»), изъ грецкихъ орьховъ («ядость изнутри выгонитъ»).

Для улучшения мыслительных способностей мозга: горчичное («память укрьпляетъ»), изъ кирпича («память приворачиваетъ»), розмариновое («память укрьпитъ и острость разума подаетъ»).

При лечении педикулеза: кедровое («вши отъ него отбьгаютъ»).

При лечении эпидемиологических болезней: инпериково («во время морового повьтрія сохраняетъ»).

\section{Сведения о маслах в Словаре Акалемии Российской (1789-1794)}

В ходе исследования мы выяснили, что некоторые из названных выше наименований масел зафиксированы в нормативном Словаре Академии Российской 17891794 гг. (далее используем сокращение - САР, сохраняем орфографию памятника письменности): анисовое [CAP I, Ст. 35], бобковое [CАР I, Ст. 241], гвоздичное [CAР II, Ст. 28], конопляное [САР III, Ст. 778], можжевеловое [САР IV, ст. 218], орьховое [CAP III, ст. 641], полынное [CAР IV, ст. 990], терпентинное [CAP VI, ст. 102]. Это свидетельствует о том, что перечисленные масла были хорошо известны. В словарной статье о бобковом масле есть указания на лечебные свойства этого вещества, и они отличны от тех, что находим в «Прохладном вертограде». Для сравнения 
представим данные письменных памятников в виде небольшой таблицы.

Различия в описании лечебного эффекта бобкового масла в указанных памятниках письменности наводят на мысль о существовании различных масел растительного происхождения, получивших одинаковое наименование. По одной версии бобковое масло - это лавровое масло, по другой - оливковое [Худин, 2021, с. 149]. Либо возникают сомнения в изученности лечебных свойств данного масла. Заметим, что медицинскую часть САР составляли ведущие русские врачи А.П. Протасов, Н.Я. Озерецковский, в компетентности которых современники не сомневались [Чернявский, с. 415].

Таблица 1.

Лечебные свойства бобкового масла

\begin{tabular}{|c|c|}
\hline $\begin{array}{c}\text { Описание бобкового масла } \\
\text { в «Прохладном вертограде» }\end{array}$ & Описание бобкового масла в САР \\
\hline $\begin{array}{l}\text { «...Силу имьетъ мягчительну, и } \\
\text { нагрьваетъ, и отворяетъ жилы за- } \\
\text { ключенныя, и исцьляетъ немочь } \\
\text { въ удьхъ, кая бываетъ отъ студе- } \\
\text { ности; такоже и коросту, и свер- } \\
\text { бежъ и нечистоту тьлесную выве- } \\
\text { детъ, такожъ и власомъ растеніе } \\
\text { творитъ» (гл. 218). }\end{array}$ & $\begin{array}{l}\text { «асло древянное, настоянное съ } \\
\text { лавровыми ягодами, употребля- } \\
\text { емое простымъ народомъ какъ } \\
\text { наружное лекарство въ ломотахъ, } \\
\text { холодныхъ опухоляхъ и поносахъ» } \\
\text { [CAР I, ст. 241]. }\end{array}$ \\
\hline
\end{tabular}

\section{Выво $\Delta ы$}

Представленный перечень позволяет представить, насколько широко использовалось масло в лечебных целях, особенно при лечении соматических заболеваний (78\% всех наименований). Разумеется, у современного человека вызывает сомнение эффективность применения какого-либо масла для лечения сразу нескольких за- болеваний, например, масло изб кирпича рекомендуется использовать для лечения 6 заболеваний. В этом смысле языковые факты «Прохладного вертограда» подтверждают известный вывод о том, что лекарственная терапия XVII-XIX вв. была малоэффективной [Сточик, 2012, с. 53]. Значительная часть применявшихся лекарств не содержала активно действующих начал и могла оказывать психотерапевтическое воздействие: помогала вера в то, что масло, по словам автора «Прохладного вертограда», собрание злых болезней разгоняет [Флоринский, 1879, c. 133]. Лекарственных средств, содержавших биоактивные компоненты было немного [Сточик, 2012, с. 53]. К тому же в лечебных целях использовались вещества, оказывающие токсическое действие [Там же]. К ним относятся соединения ртути, свинца, меди, фосфора, серы и др. В исследуемом нами источнике для лечения рекомендуется масло изъ сьры горючія, изъ купоросу. И все же указания на то, при каком недуге следует использовать то или иное масло, свидетельствуют в пользу вывода о том, что медики конца XVII-XVIII вв. придерживались концепции классификационной медицины, ориентированной на поиск специфических средств лечения для каждой «индивидуальной лечебной сущности» [Там же].

Изучение материалов «Прохладного вертограда» вносит вклад в формирование представлений о медицинских книгах как памятниках культуры. Историки считают травники, вертограды и лечебники предшественниками государственных фармакопей, поскольку они содержат описания и способы приготовления лекарственных препаратов того времени [Зелингсон, 2016, с. 234]. С этой точки зрения «Прохладный вертоград» заслуживает внимания историков русской медицины и культуры, а также исследователей, изучающих историю русского языка и историю медицинской терминологии.

\section{ЛИТЕРАТУРА}

1. Флоринский В.М. Книга, глаголемая «Прохладный вертоградъ», избранная отъ многихъ мудрецовъ о различныхъ врачевскихъ вещехъ ко здравію человьческому пристоящихъ // Русские простонародные травники и лечебники: собрание медицинских рукописей XVI и XVII столетия / [Cоч.] Проф. B.M. Флоринского. — Казань: типография Императорского университета, 1879. — С. 19-173.

2. Груздев В.Ф. Русские лечебники в собрании Пушкинского Дома // Труды Отдела древнерусской литературы / АН СССР, ИРЛИ (Пушкинский Дом); отв. ред. Д.С. Лихачев. - Л.: Наука. Ленинградское отделение, 1974. - Т. 29: Вопросы истории средневековой литературы. Памяти В.П. Адриановой-Перетц. С. $343-348$.

3. Дворецкий И.Х. Латинско-русский словарь. - 4-е изд. - М.: Русский язык, 1996. - 840 с.

4. Замкова В.В. Славянизм как стилистическая категория в русском литературном языке XVIII века. — Л.: Наука, 1975. — 223 с.

5. Зелинксон Ю.И. Регламентация изготовления лекарственных средств в России XVI—XVII веков: вертограды, фармакопеи, лечебники // Разработка и регистрация лекарственных средств. - 2016. — № 2 (15). — С. 232-234.

6. Куликов В.А. История создания общегосударственных ведомственных российских фармакопей // Вестник фармации. - 2012. - № 2 (56). - С. 55-61.

7. САР — Словарь Академии Российской: в шести томах / Российская академия наук, Отделение историко-филологических наук, Московский гуманитарный институт имени Е. Р. Дашковой. — М.: МГИ им. Е. Р. Дашковой, 1789-1794. — T. I—VI.

8. СлРЯ XI—XVII — Словарь русского языка XI—XVII вв. Вып. 1—30. — М.: Наука, 1975-2017.

9. Сточик А.М., Затравкин С.Н. Классическая медицина и ее реформирование в XVII-XIX вв. Сообщение 1. Классификационная медицина. Возникновение клинической идеи // Проблемы социальной гигиены, здравоохранения и истории медицины. — 2012. — № 1. — C. 51—55. 
10. 1Фасмер М. Этимологический словарь русского языка: В 4 т.: Пер. с нем. — 3-е изд., стереотип. — М.: Азбука-Терра, 1996. — Т. 1. — 576 с.

11. Худин К.С. Документы Аптекарского приказа (1629-1672 гг.) как исторический источник: дис. ... канд. ист. наук / Кирилл Станиславович Худин; Институт всеобщей истории Российской академии наук. - М., 2021. - 280 с.

12. Чернявский М.Н. Краткий очерк истории и проблем упорядочения медицинской терминологии // Энциклопедический словарь медицинских терминов: В 3 т. / под редакцией Б.В. Петровского. — М.: Советская энциклопедия, 1984. — Т. 3. — С. 411—425.

(с) Анциферова Ольга Николаевна (antsiferovaon@yandex.ru).

Журнал «Современная наука: актуальные проблемы теории и практики»

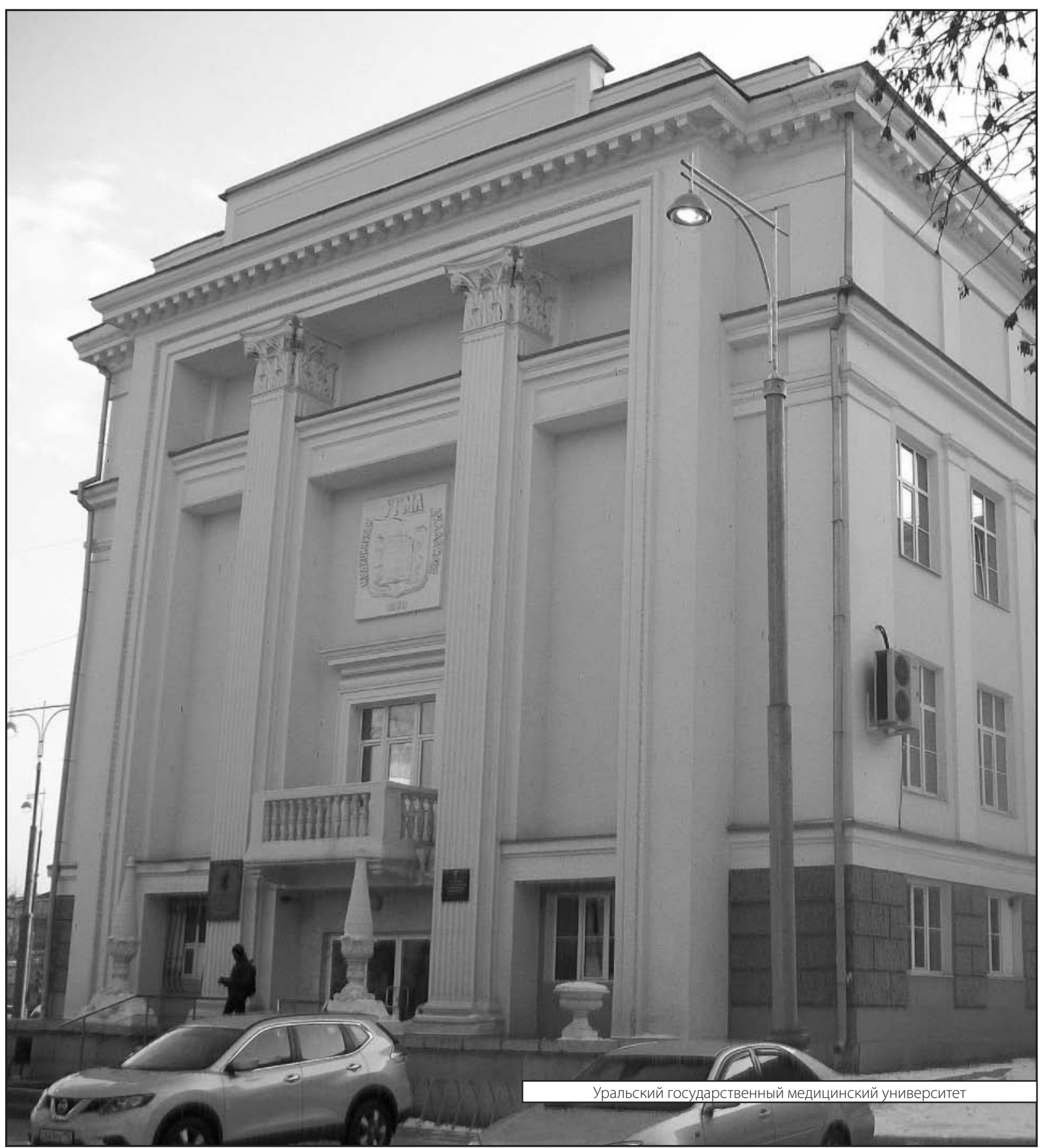

